\title{
Viewpoint Restrictions and School-Sponsored Student Speech: Avenues for Heightened Protection
}

\author{
Samuel P. Jordan†
}

Normal constitutional rules do not always apply within the schoolhouse. The Supreme Court has concluded that the constitutional rights generally available in other social situations may not exist - at least not coextensively - in the educational context.' This general proposition embraces in particular the expressive rights of students. Although the First Amendment rights of students do not disappear when they enter a school building, they may be circumscribed. ${ }^{2}$

Student expression is clearly subject to limitation when it is sponsored by the school. In Hazelwood School District v Kuhlmeier, ${ }^{3}$ the Supreme Court determined that restrictions on school-sponsored student speech-defined to include speech that is in some respect affirmatively promoted by the school-are permissible if reasonably related to valid pedagogical purposes. ${ }^{4}$ Given the general judicial practice of deferring to the expertise of school authorities in deciding what constitutes a valid pedagogical purpose,' the Hazelwood standard accords wide latitude to the authorities regarding school-sponsored student expression.

Restrictions on school-sponsored expression are either contentbased, prohibiting an entire subject of discourse, or viewpoint-based, prohibiting discussion about a subject from a particular perspective." Since content-based restrictions limit all expression on a subject, regardless of perspective, they do not discriminate among speakers and points of view on that subject, and judicial deference to school offi-

$\dagger$ B.A. 1998, Rhodes College; J.D. Candidate 2004, The University of Chicago; M.P.P. Candidate 2004, The University of Chicago.

1 See, for example, Vernonia School District 47J v Acton, 515 US 646, 655 (1995) (arguing that the educational context "permit[s] a degree of supervision and control that could not be exercised over free adults"); Bethel School District No. 403 v Fraser, 478 US 675, 682 (1986) (concluding that free speech rights for public school students "are not automatically coextensive with the rights of adults in other settings").

2 See discussion in Part I.A.

3484 US 260 (1988).

4 Id at 273.

5 For discussion and criticism of this deference, see Part II.B.2.

6 For discussion of the distinctions between viewpoint and content restrictions, see Marjorie Heins, Viewpoint Discrimination, 24 Hastings Const L Q 99, 105-15 (1996) (tracing the history of the Supreme Court's proscription of viewpoint-discriminatory speech regulations and distinguishing the treatment of content-based restrictions). 
cials regarding the pedagogically appropriate scope of discussion may be in order. However, when the speech regulation addresses not the subject matter itself but a particular point of view toward it, the broad regulatory authority effectively conferred by judicial deference is problematic.

As a general matter, speech restrictions based on the viewpoint expressed are constitutionally suspect. 'Indeed, one prominent constitutional scholar has observed that such restrictions "have never been upheld." While the suspect nature of viewpoint-based restrictions is generally true without regard to the particular context of the speech, the Hazelwood Court, in dealing with speech in the schoolhouse context, did not reach specific conclusions on viewpoint restrictions of student expression. In the absence of a specific holding to the contrary, the Ninth and Eleventh Circuits have refused to create a constitutional exception to allow viewpoint restrictions on student expression." But the First, Third, and Tenth Circuits have read Hazelwood to establish just such an exception."'

If a constitutional exception permitting restrictions on student points of view is not compelled by Hazelwood, it is at least arguably consistent with a fair reading of the decision." Nevertheless, such an exception threatens the First Amendment rights of studentsespecially given the more expansive interpretation of Hazelwood by some lower courts - and is inconsistent with fundamental educational principles. Although it may be appropriate for school officials to prefer a particular viewpoint, and even to advocate it, they should not be permitted to advance that viewpoint simply by suppressing all others.

This Comment will evaluate viewpoint-based restrictions on school-sponsored speech in the context of recent interpretations of the Hazelwood standard. It will then offer suggestions to improve the protection of viewpoints within the Hazelwood framework. Part I.A reviews judicial precedent involving school speech, paying particular attention to the Supreme Court's attempts to account for the competing interests of the student and the school. Part I.B describes the con-

7 See, for example, Rosenberger v Rector and Visitors of University of Virginia, 515 US 819 , 828-29 (1994) ("Discrimination against speech because of its message is presumed to be unconstitutional."); RAV v City of St. Paul, 505 US 377,391-94 (1992) (striking down a hate speech ordinance prohibiting only "fighting words" that "communicate messages of racial, gender, or religious intolerance," as it would function as a viewpoint discrimination by "licens[ing] one side of a debate to fight freestyle, while requiring the other to follow Marquis of Queensberry rules"); Castorina v Madison County School Board, 246 F3d 536, 540 (6th Cir 2001) ("[V]iewpointspecific restrictions are an egregious violation of the First Amendment.").

8 Erwin Chemerinsky, Content Neutrality as a Central Problem of Freedom of Speech: Problems in the Supreme Court's Application, 74 S Cal L Rev 49, 56 (2000).

9 See discussion in Part I.B.1.

10 See discussion in Part I.B.2.

11 See discussion in Part II.A. 
flicting conclusions reached by lower courts regarding the specific question of viewpoint neutrality in the context of school-sponsored speech. Part II examines these conclusions and suggests that none is satisfactory in light of the evolving interpretation of Hazelwood. Finally, Part III presents two possible modifications to the current application of Hazelwood. The first emphasizes the legitimacy of the pedagogical purpose asserted by the school, and the second emphasizes the potential for misattribution of the speech at issue. Each would increase the level of protection accorded to student viewpoints. However, because it is more flexible and more consistent with the Hazelwood decision, the first proposal is preferable.

\section{Current School Speech Doctrine}

Government regulation of speech in schools has been the subject of considerable judicial attention. Limitations on the speech of those who lack official school capacity often reflect a tension between the expressive rights of the individual speaker and the interests of the school as custodian and educator. ${ }^{12}$ This tension is particularly pronounced in the case of student speech. The Supreme Court has clearly affirmed that First Amendment protection of student expression does not cease in the school context, ${ }^{13}$ but it has also acknowledged the need to weigh this protection against the pedagogical interests of school authorities. ${ }^{14}$ In attempting to strike such a balance regarding limitations on viewpoint expression, however, lower courts have reached inconsistent results, disagreeing on which doctrines to apply and how to interpret Supreme Court precedent.

12 The most commonly regulated speech in the public school context is official speech speech rendered by persons in their capacity as school officials, with the school system itself effectively acting as the speaker. Courts ordinarily sustain limitations on this form of school speech, reasoning that an educational entity should have a considerable degree of control over its own expression. See, for example, Downs v Los Angeles Unified School District, 228 F3d 1003, 1013-17 (9th Cir 2000) (holding that the First Amendment does not bar a school board from removing a teacher's postings with which it disagrees from a bulletin board constituting a "vehicle for conveying a message from the school district"), cert denied, 532 US 994 (2001); Muir v Alabama Educational Television Commission, 688 F2d 1033, 1044 (5th Cir 1982) ("[T]he First Amendment does not preclude the government from exercising editorial control over its own medium of expression."). For a general discussion, see Mark G. Yudof, When Government Speaks (California 1983).

13. See Tinker v Des Moines Independent Community School District, 393 US 503, 506 (1969) ("It can hardly be argued that either students or teachers shed their constitutional rights to freedom of speech or expression at the schoolhouse gate. This has been the unmistakable holding of this Court for almost 50 years.").

14 See id at 507 (acknowledging the "comprehensive authority of the States and of school officials ... to prescribe and control conduct in the schools," but requiring that such regulations be "consistent with fundamental constitutional safeguards"). 


\section{A. Forms of Student Speech}

Courts have long observed that part of the role of public schools is to prepare students for citizenship by instilling values necessary for democratic participation. "In fulfilling this role, schools must deal with students who are not yet "possessed of that full capacity for individual choice which is the presupposition of First Amendment guarantees." As a result, the school has an interest in regulating the marketplace of ideas" that is manifested in a "custodial and tutelary" authority "permit[ting] a degree of supervision and control that could not be exercised over free adults."

This authority, however, is not absolute. Instead, it is tempered by a concern that a school's tutelary and custodial authority not be used to "strangle the free mind at its source." Accordingly, the Supreme Court has recognized that a school's interest in regulating school speech, and its authority to do so, must be balanced against the student's countervailing interest in free expression. The struggle to reconcile these competing interests is most clearly evident in cases involving two different forms of student speech-pure student speech and school-sponsored speech - each of which is the subject of leading Supreme Court decisions.

\section{Pure student speech.}

Not all student expression is school-specific. Some speech is of the sort that may take place anywhere yet happens to occur on school premises. Such speech, which the Supreme Court denominates "pure" student speech, was the subject of dispute in Tinker $v$ Des Moines Independent Community School District. ${ }^{21}$ That case involved three students suspended for wearing black armbands in protest of the Vietnam War.' The school invoked its custodial responsibilities as a de-

15 See Ambach $v$ Norwick, 441 US 68, 76-77 (1979) (describing the importance of schools "in the preparation of individuals for participation as citizens" and in the "inculcat[ion of] fundamental values necessary to the maintenance of a dèmocratic political system").

16 Tinker, 393 US at 515 (Stewart concurring).

17 See Zykan v Warsaw Community School Corp, 631 F2d 1300, 1304 (7th Cir 1980) ("A high school student's lack of the intellectual skills necessary for taking full advantage of the marketplace of ideas engenders a correspondingly greater need for direction and guidance from those better equipped by experience and reflection to make critical educational choices.").

18 Vernonia School District 47J v Acton, 515 US 646, 655 (1995).

19 West Virginia State Board of Education v Barnette, 319 US 624, 637 (1943). The Court also noted that school districts perform their "delicate" function of "educating the young for citizenship" subject to "scrupulous protection of Constitutional freedom of the individual." Id at 638.

20393 US 503 (1969). In Tinker, the Court concluded that the speech in question was "closely akin to 'pure speech' which, we have repeatedly held, is entitled to comprehensive protection under the First Amendment." Id at 505-06.

$21 \quad$ Id at 504. 
fense for its actions, ${ }^{22}$ but the Court nevertheless held that the suspensions unconstitutionally infringed the students' expressive rights. ${ }^{23}$ In doing so, the Court concluded that "[i]n the absence of a specific showing of constitutionally valid reasons to regulate their speech, students are entitled to freedom of expression of their views. ${ }^{24}$ A school has a constitutionally valid reason to regulate student speech only when the school's interest in maintaining discipline, promoting an effective learning environment, and shaping pupils into citizens outweighs the student's interest in free expression.

Tinker sets a high bar for speech restrictions on pure student speech. Restrictions made simply to avoid controversy-such as those examined in Tinker-are not permitted. ${ }^{26}$ Instead, the student's expressive rights predominate and the speech must be tolerated, even if it leads to "the discomfort and unpleasantness that always accompany an unpopular viewpoint." ${ }^{27}$ However, occasions exist where pure student speech is subject to regulation by school authorities. For example,

22 Id at $509 \mathrm{n} 3$ (quoting from a school memorandum justifying the suspensions in part because "any kind of a demonstration ... might evolve into something which would be difficult to control," and from a school official's trial testimony that "the schools are no place for demonstrations").

23 Id at 514 ("In the circumstances of the present case, the prohibition of the silent, passive 'witness of the armbands,' as one of the children called it, is ... offensive to the Constitution's guarantees.").

24 Id at 511 (reasoning that censorship of pure student expression must be justified, as "state-operated schools may not be enclaves of totalitarianism").

25 See id at 507 ("[T]he Court has repeatedly emphasized the need for affirming the comprehensive authority of the States and of school officials, consistent with fundamental constitutional safeguards, to prescribe and control conduct in the schools."). See also Epperson v Arkansas, 393 US 97, 104 (1968) ("By and large, public education in our Nation is committed to the control of state and local authorities. Courts do not and cannot intervene in the resolution of conflicts which arise in the daily operation of school systems and which do not directly and sharply implicate basic constitutional values.").

The balancing inherent in student speech cases may not always be explicit. Nevertheless, the Supreme Court has consistently acknowledged both sets of competing rights when contemplating restrictions of student speech. Explicit or not, the line of school speech decisions reflects conclusions about the relative magnitudes of the opposing interests. See Rosemary C. Salomone, Free Speech and School Governance in the Wake of Hazelwood, 26 Ga L Rev 253, 255-71 (1992) (tracing the student rights/school control dichotomy in Supreme Court school speech jurisprudence from the 1940s through the 1980s).

26 See Tinker, 393 US at 508 (rejecting the notion that an "undifferentiated fear or apprehension of disturbance" can justify a pure speech restriction).

27 Id at 509. See also id at 508-09 (internal citation omitted):

Any departure from absolute regimentation may cause trouble. Any variation from the majority's opinion may inspire fear. Any word spoken, in class, in the lunchroom, or on the campus, that deviates from the views of another person may start an argument or cause a disturbance. But our Constitution says we must take this risk ... and our history says that it is this sort of hazardous freedom - this kind of openness - that is the basis of our national strength and of the independence and vigor of Americans who grow up and live in this relatively permissive, often disputatious, society. 
Tinker itself indicates that when speech disrupts academic activities or invades the rights of others, the balance of interests shifts and regulation becomes permissible. ${ }^{2 x}$ Later cases add that student expression that "undermine[s] the school's basic educational mission"-such as vulgar or lewd speech-is subject to restriction, even though it may not create a classroom disruption."

\section{School-sponsored student speech.}

In the landmark case of Hazelwood School District v Kuhlmeier," the Supreme Court recognized school-sponsored speech as a separate form of schoolhouse expression. Hazelwood upheld a principal's decision to excise student articles written for the school newspaper. ${ }^{31}$ To do so, the Court first determined that the pure speech standard established in Tinker did not apply to the expression at issue. ${ }^{32}$ Instead, the school's affirmative promotion of the school-sponsored newspaper justified increased regulatory authority."

The Court cited two primary justifications for the heightened interest of school authorities when student speech is school-sponsored. First, the educational context of the speech-including involvement of faculty members and the pursuit of educational objectives in the sponsored activity-implicates the school's custodial and tutelary responsibilities more directly. ${ }^{34}$ Second, a school's promotion of speech introduces the possibility that the expression will be attributed to the school itself." Speech that bears the imprimatur of the school resembles official speech, leaving the school free to employ reasonable

28 See id at 513 (explaining that otherwise-protected student expression that poses such a threat, "whether it stems from time, place, or type of behavior ... is, of course, not immunized by the constitutional guarantee of freedom of speech").

29 Bethel School District No. 403 v Fraser, 478 US 675, 685-86 (1986) (authorizing the punishment of a student for giving a "vulgar and lewd speech" at a public school assembly). See also Hazelwood, 484 US at 271 n 4 (distinguishing Fraser's "plainly offensive"-and thus inappropriate for school even if it does not materially disrupt classwork - justification for school censorship from Tinker's dangerous propensity justification for school censorship).

30484 US 260.

3 Id at 263-64. One of the articles in question dealt with teenage pregnancy, and the other with the impact of divorce.

32 Id at 270-7.1 ("The question whether the First Amendment requires a school to tolerate particular student speech - the question that we addressed in Tinker-is different from the question whether the First Amendment requires a school affirmatively to promote particular student speech.").

33. See id at 271 (holding that "[e]ducators are entitled to exercise greater control over ... [school-sponsored] student expression" than over pure student speech).

34 See id (finding regulation permissible "to assure that participants learn whatever lessons the activity is designed to teach, [and] that readers or listeners are not exposed to material that may be inappropriate for their level of maturity").

35 See id (stating that schools should not be compelled to promote speech that "students, parents, and members of the public might reasonably perceive to bear the imprimatur of the school"). 
measures to guard against misattribution. ${ }^{30}$ Because of the educational context and the perception of imprimatur, Hazelwood authorizes regulation of school-sponsored speech so long as the regulation is "reasonably related to legitimate pedagogical concerns."

\section{B. Viewpoint Discrimination and Hazelwood}

Hazelwood does not explicitly discuss whether regulation of school-sponsored speech can be based on the viewpoint expressed. This issue has since been addressed by five federal courts of appeal, and each has used suggestions from Hazelwood to substantiate varying results. The Ninth and Eleventh Circuits have used the conclusions of Hazelwood's forum analysis to justify a requirement of viewpoint neutrality. The First, Third, and Tenth Circuits have instead relied on the special characteristics of the school environment, together with the absence of an explicit requirement of viewpoint neutrality in Hazelwood, to justify an acceptance of viewpoint restrictions of school-sponsored speech. ${ }^{3 .}$

1. Viewpoint discrimination prohibited: traditional nonpublic forum analysis.

The permissibility of speech restrictions made by a government entity depends in large measure on the conclusions of a court's forum analysis. ${ }^{39}$ Speech restrictions in public forums are difficult to sustain,"

36 See id (deeming regulation to ensure "that the views of the individual speaker are not erroneously attributed to the school" to be permissible). See also Downs v Los Angeles Unified School District, 228 F3d 1003, 1009 (9th Cir 2000) (noting that when "speech or expression begins to implicate the school as speaker, First Amendment rights have been limited"). For a discussion of a school's ability to restrict official speech, see note 12 .

37 Hazelwood, 484 US at 273. See also id at 271-72 (providing examples of permissible regulations under this standard, such as censoring student newspaper articles that are "ungrammatical, poorly written, inadequately researched, biased or prejudiced, vulgar or profane, or unsuitable for immature audiences," or school-sponsored speech that "might reasonably be perceived to advocate drug or alcohol use, irresponsible sex, or conduct otherwise inconsistent with the shared values of a civilized social order, or to associate the school with any position other than neutrality on matters of political controversy") (internal citation and quotation marks omitted).

38 Compare Planned Parenthood v Clark County School District, 941 F2d 817 (9th Cir 1991); Searcey v Harris, 888 F2d 1314 (11th Cir 1989), with Fleming v Jefferson County School District R-1, 298 F3d 918 (10th Cir 2002), cert denied, 537 US 1110 (2003); C.H. v Oliva, 195 F3d 167 (3d Cir 1999); Ward v Hickey, 996 F2d 448 (1st Cir 1993).

39 For a discussion of the importance of forum conclusions on the permissibility of speech restrictions, see generally Steven G. Gey, Reopening the Public Forum-From Sidewalks to Cyberspace, 58 Ohio St L J 1535, 1538-66 (1998) (reviewing the evolution of the current public forum doctrine).

40 Generally, a content-based restriction in a public forum is impermissible unless it is "necessary to serve a compelling state interest and ... narrowly drawn to achieve that end." Perry Education Association v Perry Local Educators' Association, 460 US 37, 45 (1983). Content-neutral restrictions on "time, place, and manner of expression" are permissible if they are 
while speech restrictions in nonpublic forums are relatively easy to sustain." An educational facility is considered a public forum only if school officials have intentionally opened it "for indiscriminate use by the general public" or a segment of the public. Since the school newspaper in Hazelwood had not been opened to public participation or discourse but had been reserved for a curricular purpose-namely, to teach journalism to enrolled students - it was determined to be a nonpublic forum. ${ }^{43}$

If the traditional requirements for a nonpublic forum apply to the educational context, then viewpoint neutrality should be required under Hazelwood. In Cornelius v NAACP Legal Defense and Educational Fund, the Supreme Court established that restrictions on speech in a nonpublic forum may be "based on subject matter and speaker identity so long as the distinctions drawn are reasonable in light of the purpose served by the forum and are viewpoint neutral.", Viewpoint neutrality is thus unambiguously required under the standard nonpublic forum analysis. If that analysis applies to schoolsponsored speech, then viewpoint neutrality must be a prerequisite of any limitation of such speech. Both the Ninth and Eleventh Circuits have reached just this conclusion.

In Searcey v Harris, ${ }^{45}$ the Eleventh Circuit reviewed restrictions on information distributed at a "Career Day" program sponsored by the school board at the local high school. ${ }^{47}$ In effect, the board's regulations distinguished among potential speakers on the basis of viewpoint, as they precluded the distribution of information that would discourage students from entering the military. The court concluded

\footnotetext{
"narrowly tailored to serve a significant government interest, and leave open ample alternative channels of communication." Id.

41 See notes $44-45$ and accompanying text for a discussion of speech restrictions in nonpublic forums.

42 Perry, 460 US at 47 (explaining that the occasional use of internal school mail by outside groups does not dictate that the school mailboxes and interschool delivery system are a public forum, because the school's granting selective access on a case-by-case basis falls short of permitting wholesale use by the general public). With respect to the intentionality requirement, see Cornelius v NAACP Legal Defense and Educational Fund, Inc, 473 US 788, 802 (1985) ("The government does not create a public forum by inaction or by permitting limited discourse, but only by intentionally opening a nontraditional forum for public discourse.").

43 See Hazelwood, 484 US at 270 (holding that the student newspaper was "a supervised learning experience for journalism students" rather than a public forum for "student reporters and editors, or [ ] the student body generally"). This conclusion has been met with criticism. See, for example, C. Thomas Dienes and Annemargaret Connolly, When Students Speak: Judicial Review in the Academic Marketplace, 7 Yale L \& Pol Rev 343,371-76 (1989).

$44 \quad 473$ US 788 (1985).

45 Id at 806 ("[T]he government violates the First Amendment when it denies access to a speaker solely to suppress the point of view he espouses on an otherwise includible subject.").

46888 F2d 1314 (11 th Cir 1989).

47 Id at 1315 .

48 Id at 1317-18. These regulations included a requirement that "information shall be con-
} 
that Hazelwood was "merely an application of [the Cornelius] standard to a curricular program," meaning that Hazelwood does nothing to displace the viewpoint neutrality required by Cornelius." Under this reading, even reasonable regulations that serve legitimate pedagogical concerns are impermissible if they discriminate on the basis of viewpoint. ${ }^{.0}$ The Searcey court concluded that the School Board intended the Career Day activities to teach students about career and educational opportunities and to motivate students to pursue them." The court permitted regulations that made reasonable content-based restrictions on the basis of these pedagogical intentions, ${ }^{52}$ but struck down regulations that made viewpoint-based restrictions."

Similarly, in Planned Parenthood of Southern Nevada, Inc $v$ Clark County School District, ${ }^{54}$ the Ninth Circuit, en banc, upheld the rejection of advertisements for school publications submitted by a familyplanning organization." In its statement of requirements under Hazelwood, the court incorporated the traditional Cornelius standard without discussion. .6 $^{6}$ Under the court's analysis, viewpoint neutrality was required under Hazelwood. The court nevertheless concluded that this requirement was met and that the restrictions at issue were content-based and therefore permissible."

veyed in as positive and encouraging a manner as possible so as to be motivational to students" and a prohibition against presenters "whose primary focus or emphasis is to discourage a student's participation in a particular career field." Id at 1317.

49 Id at 1319 ("Hazelwood [ ] does not alter the test for reasonableness in a nonpublic forum such as a school but rather provides the context in which the reasonableness of regulations should be considered."). See also id at 1319 n 7 ("Although the Supreme Court did not discuss viewpoint neutrality in Hazelwood, there is no indication that the Court intended to drastically rewrite First Amendment law to allow a school official to discriminate based on a speaker's views. ... Hazelwood acknowledges a school's ability to discriminate based on content not viewpoint.").

50 See Cornelius, 473 US at 811 ("The existence of reasonable grounds for limiting access to a nonpublic forum, however, will not save a regulation that is in reality a façade for viewpointbased discrimination.").

51 Searcey, $888 \mathrm{~F} 2 \mathrm{~d}$ at 1320.

52 Id at $1320-24$.

53 Id at 1325 ("Although Hazelwood provides reasons for allowing a school official to discriminate based on content, we do not believe it offers any justification for allowing educators to discriminate based on viewpoint.").

54941 F2d 817 (9th Cir 1991) (en banc).

55 Id at 830 .

56 Id at 829 (citing Hazelwood for its nonpublic forum finding, and then citing Cornelius for the requirement of viewpoint neutrality within a nonpublic forum). This conclusion was criticized but followed by a subsequent Ninth Circuit panel. See Downs v Los Angeles Unified School District, 228 F3d 1003, 1010-11 (9th Cir 2000).

57 Clark, 941 F2d at 829 ("The schools' refusal to publish Planned Parenthood's advertisements was viewpoint neutral."). 
2. Viewpoint discrimination permitted: "special characteristics" analysis.

In contrast to the decisions of the Ninth and Eleventh Circuits, the First, Third, and Tenth Circuits have concluded that Hazelwood contains no implicit requirement of viewpoint neutrality. courts have subordinated the standard requirement of viewpoint neutrality in Cornelius s" to the language in Tinker declaring that First Amendment rights are available only as "applied in the light of the special characteristics of the school environment." ${ }^{\text {, }}$ The Supreme Court has relied on these special characteristics to justify deviations from traditional constitutional requirements."

The Third Circuit invoked the special characteristics of the educational environment to sustain a school's viewpoint-based restrictions in C.H. v Oliva. ${ }^{62}$ Upholding a teacher's decision to forbid a student from reading a religious story to his first-grade classmates, the court held that "a viewpoint-based restriction on student speech in the classroom may be reasonably related to legitimate pedagogical concerns and thus permissible." While the language of Oliva did not acknowledge any deviation from precedent, it is difficult to reconcile with Cornelius, which unambiguously requires restrictions to be viewpoint neutral regardless of their reasonableness. ${ }^{64}$ The Third Circuit rationalized its position by asserting that the language used in Hazelwood actually contemplated viewpoint-based restrictions on schoolsponsored speech, and by arguing that the long-recognized custodial

58 See note 38.

59 See notes 44-45 and accompanying text.

60 Tinker, 393 US at 506.

61 For example, the Court has held that traditional Fourth Amendment rules regarding searches and seizures are not appropriate in the educational context. See Vernonia School District $47 J v$ Acton, 515 US 646, 656 (1995) (stating that while students "assuredly do not 'shed their constitutional rights ... at the schoolhouse gate,' the nature of those rights is what is appropriate for children in school"), quoting Tinker, 393 US at 506; New Jersey v TLO, 469 US 325, 337-43 (1985) (balancing students' Fourth Amendment rights against schools' interest in maintaining order, and dispensing with the traditional warrant and probable cause requirements for searches and seizures in schools).

62 195 F3d 167, 174-76 (3d Cir 1999), affd in part and revd in part, 226 F3d 198 (2000) (en banc) (dismissing on jurisdictional grounds), cert denied as Hood v Medford Township Board of Education, 533 US 915 (2001). Prior to Oliva, the First Circuit asserted without discussion that viewpoint neutrality was not required under Hazelwood. See Ward v Hickey, 996 F2d 448, 454 (1st Cir 1993) (asserting that Hazelwood "did not require that school regulation of schoolsponsored speech be viewpoint neutral").

63 Oliva, 195 F3d at 172 (deriving the permissibility of viewpoint-discriminatory restrictions on school-sponsored expression from dicta in Hazelwood listing examples of permissible restrictions, including some that were not viewpoint neutral).

64 Cornelius, 473 US at 806 ("Control over access to a nonpublic forum can be based on subject matter and speaker identity so long as the distinctions drawn are reasonable in light of the purpose served by the forum and are viewpoint neutral."). 
responsibilities of schools - which authorize the promotion of certain viewpoints over others-were included in the scope of legitimate pedagogical concerns. Thus, the court reasoned, in situations involving school-sponsored speech, "viewpoint neutrality is neither necessary nor appropriate, as the school is there responsible for 'determin[ing] the content of the education it provides." ${ }^{65}$

The Tenth Circuit reached essentially the same conclusion, on much the same reasoning, in Fleming v Jefferson County School District $R-1,{ }^{\text {th }}$ a recent case involving a tile-painting project designed to commemorate the deaths of students at Columbine High School. ${ }^{67}$ In sustaining the school's policy of excluding dates, names, and religious messages from the tiles, the court considered the issue of viewpoint neutrality at length before concluding that Hazelwood permits viewpoint-based regulations of school-sponsored speech. ${ }^{68}$ Unlike the Third Circuit in Oliva, the Tenth Circuit in Fleming made its departure from the Cornelius standard explicit. ${ }^{69}$ But as in Oliva, the Fleming court's justification relies heavily on the special responsibilities of the school, which Hazelwood explicitly acknowledged to include the inculcation of values, and which-according to the Fleming court-"often will turn on viewpoint-based judgments."

\section{Problems with Current Approaches to Viewpoint-Based RESTRICTIONS UNDER HAZELWOOD}

Courts evaluating viewpoint restrictions on school-sponsored speech have done so categorically: Either Hazelwood requires viewpoint neutrality or it does not. Neither of these per se approaches is satisfactory because neither retains the flexibility to recognize and balance the competing interests of the school and the student. Cate-

65 Oliva, 195 F3d at 173, quoting Rosenberger $v$ Rector and Visitors of University of Virginia, 515 US 819,833 (1995).

66298 F3d 918 (10th Cir 2002), cert denied, 537 US 1110 (2003).

67 Id at $920-21$.

68 Id at 926.

69 "In light of the Court's emphasis on the 'special characteristics of the school environment,' and the deference to be accorded to school administrators about pedagogical interests, it would make no sense to assume that Hazelwood did nothing more than simply repeat the traditional nonpublic forum analysis." Id, quoting Hazelwood, 484 US at 266. The court also found it significant that the Supreme Court did not mention Cornelius in its Hazelwood decision, even though Cornelius had already been decided. Id at 928 ("Starting with Hazelwood itself, the case makes no mention that the school's restrictions must be neutral with respect to viewpoint, although the Court had already decided [Cornelius], ... which states that government restrictions in a nonpublic forum must not discriminate based on viewpoint.").

70 Id at 928 ("[Hazelwood's] specific reasons supporting greater control over schoolsponsored speech . . . often will turn on viewpoint-based judgments. . . No doubt the school could promote student speech advocating against drug use, without being obligated to sponsor speech with the opposing viewpoint. Hazelwood entrusts to educators these decisions."). 
gorical proscription of viewpoint limitations excludes appropriate consideration of the special characteristics of the school environment, which in some circumstances may warrant viewpoint restrictions. At the same time, categorical acceptance of viewpoint limitations denies sufficient protection of expressive rights, especially given the deferential attitude of the courts toward school authorities.

\section{A. Categorical Denial of Viewpoint Restrictions}

A categorical rule prohibiting viewpoint-based restrictions has some appeal. First, as a rule of general application, it has the advantage of administrative simplicity." Second, it explicitly accounts for the importance of student viewpoints. Third, it is consistent with prior Supreme Court cases, which have rejected viewpoint-based restrictions in every instance.

Nevertheless, a fair reading of Hazelwood suggests that the Supreme Court intended that some viewpoint-based restrictions of school-sponsored speech would be permissible. ${ }^{72}$ The Court made its regard for the special characteristics of schools unambiguous." In addition, just three years before Hazelwood, the Court invoked these characteristics to support deviation from traditional Fourth Amendment requirements in the context of school searches and seizures. ${ }^{74}$ So it is reasonable to infer that the Court did not intend the Hazelwood standard to be a simple application of traditional rules. This inference is further supported by the fact that the Hazelwood Court made no explicit mention of a requirement of viewpoint neutrality, despite the fact that the traditional requirement of viewpoint neutrality for nonpublic forums had been established in Cornelius three years earlier. Moreover, the Court illustrated its position using examples

71 Of course, this advantage would apply equally to a contrary rule permitting viewpointbased restrictions.

72 For a fuller discussion of this argument, see Janna J. Annest, Comment, Only the News That's Fit to Print: The Effect of Hazelwood on the First Amendment Viewpoint-Neutrality Requirement in Public School-Sponsored Forums, 77 Wash L Rev 1227, 1247-59 (2002) (highlighting the absence of an explicit viewpoint-neutrality requirement in Hazelwood, and urging the importance of a school's right, as a dual agent of the state and parents, to inculcate community viewpoints; and arguing that eliminating the distinction between viewpoint and content restrictions avoids doctrinal confusion without sacrificing First Amendment rights); Brian S. Black, Note, The Public School: Beyond the Fringes of Public Forum Analysis?, 36 Vill L Rev 831,85970 (1991) (arguing that viewpoint discriminations are endemic in public school systems that impart knowledge and values, and that Hazelwood permits reasonable viewpoint discriminations).

73 Hazelwood, 484 US at 266-67 (acknowledging that students' First Amendment rights may be limited because of the special characteristics of the school environment).

74 New Jersey $v$ TLO, 469 US 325, 337-43 (1985) (dispensing with the traditional warrant and probable cause requirements for searches and seizures in schools).

75 See Hazelwood, 484 US at 267-70. The Court concluded that school officials could make restrictions "in any reasonable manner." Id at 270 . 
that restrict viewpoints. For instance, restriction of a "Santa Claus does not exist" viewpoint may be appropriate in the context of a first-grade classroom due to the emotional maturity of the students involved. ${ }^{76}$ These examples raised the ire of Justice Brennan, who warned that undesirable viewpoint restrictions might result." Presumably, he would not have done so absent a belief that the majority opinion contemplated at least the possibility of viewpoint-based restrictions. Taken together, the Court's analysis in Hazelwood suggests that a school's interest in fulfilling its legitimate responsibilities may at times outweigh a student's interest in unlimited viewpoint expression. Therefore, regardless of its appeal, a categorical rule proscribing viewpoint restrictions does not appear to be in order.

\section{B. Categorical Acceptance of Viewpoint Restrictions}

In the abstract, the mere possibility of viewpoint-based restrictions of student school-sponsored speech is not objectionable. As just discussed, such a possibility seems consistent with the Court's opinion in Hazelwood. Furthermore, it recognizes the important and distinctive roles that schools perform - roles sufficient to qualify schools for special constitutional treatment in certain circumstances.

However, the development of Hazelwood jurisprudence raises some practical concerns regarding the permissibility of viewpointbased restrictions. Over the past fifteen years, school authorities have sought to place school speech within the ambit of Hazelwood in order to take advantage of its relatively lenient requirements and thereby to enhance their regulatory discretion. ${ }^{78}$ These efforts are sensible.

76 See id at 272. The Court further posited that schools

must also retain the authority to refuse to sponsor student speech that might reasonably be perceived to advocate drug or alcohol use, irresponsible sex, or conduct otherwise inconsistent with "the shared values of a civilized social order," or to associate the school with any position other than neutrality on matters of political controversy.

Id, quoting Bethel School District No. 403 v Fraser, 478 US 675, 683 (1986). The Santa Claus example would almost certainly be a viewpoint-based restriction, since speech concerning Santa's existence presumably would be permitted.

77 Hazelwood, 484 US at 286-88 (Brennan dissenting).

78 As part of the same effort to increase regulatory discretion, schools have also attempted to bring cases under Fraser in order to take advantage of its vague requirements. See Andrew D.M. Miller, Balancing School Authority and Student Expression, 54 Baylor L Rev 623, 662 (2002). Efforts to expand the scope of Hazelwood and Fraser are both designed to escape the relatively strict requirements for restrictions under Tinker. The Supreme Court's introduction of relatively lenient requirements under Hazelwood and Fraser, together with the willingness of lower courts to apply those requirements broadly, have led some commentators to question the current status of Tinker. See Erwin Chemerinsky, Students Do Leave Their First Amendment Rights at the Schoolhouse Gates: What's Left of Tinker?, 48 Drake L Rev 527, 541-42 (2000) (noting that subsequent cases "are much closer to Justice Black's dissent than to Justice Fortas's majority opinion [in Tinker]," but suggesting that noncurricular student speech that does not disrupt school activities may still enjoy heightened constitutional protection). 
Rather than demonstrate that a restriction is necessary to avoid substantial disorder or material disruption of classwork - as would be required under Tinker-schools prefer to argue for an expansive definition of school-sponsored speech and to show only that a restriction is "reasonably related to legitimate pedagogical concerns." Many courts have been willing to acquiesce to these efforts. Specifically, courts have accepted very broad definitions of school-sponsored speech and legitimate pedagogical concerns, and have deferred to a school's identification of both. Applied to cases involving viewpoint-based restrictions, these developments indicate a troubling lack of protection for student expression.

\section{Defining school-sponsored speech: the scope of Hazelwood.}

The applicability of Hazelwood requires an initial judicial determination that the expression in question is school-sponsored. This determination depends on whether the speech is affirmatively promoted by the school - that is, whether it occurs in an educational context and may reasonably be perceived to bear the school's imprimatur." In practice, a few courts seem to be satisfied if the speech simply takes place in an educational context, as exemplified by the Tenth Circuit's opinion in Fleming, which reasoned that the Supreme Court's definition of school-sponsored speech "means activities that affect learning, or in other words, affect pedagogical concerns." ${ }^{\text {,"1 }}$ This treatment conflates the two inquiries inherent in the Hazelwood standard. Rather than analyze whether the speech is school-sponsored and then whether the restriction sought is permissible, Fleming simply considers speech school-sponsored if a restriction applicable to schoolsponsored speech has been placed upon it. The determination of school sponsorship as a prerequisite for applying Hazelwood is thus eliminated, and the entire inquiry is instead focused upon the restric-

79 Hazelwood, 484 US at 273. See also Part I.A.2 (explaining the standard's justification).

80 See notes 34-37 and accompanying text.

81 Fleming v Jefferson County School District R-1, 298 F3d 918, 925 (10th Cir 2002) (glossing Hazelwood's language that school-sponsored activities are those "'designed to impart particular knowledge or skills to student participants and audiences"'), quoting Hazelwood, 484 US at 271. This conclusion tracks an early law review article suggesting that Hazelwood's school sponsorship standard requires only the "presence of an education-related activity." Bruce C. Hafen, Hazelwood School District and the Role of First Amendment Institutions, 1988 Duke L J 685,693 . However, not all courts have adopted this expansive approach. See, for example, Westfield High School L.I.F.E. Club v City of Westfield, 249 F Supp 2d 98, 117 (D Mass 2003) (rejecting the notion that student group activities taking place within the school are school-sponsored, because such a "definition of 'school-sponsored' would devoid that term of any helpful meaning"). See also Part III.B. 
tion. The ultimate effect of this conflation is to increase the applicability of Hazelwood.

2. Defining legitimate pedagogical concerns: judicial deference in Hazelwood.

Courts have also embraced a broad conception of legitimate pedagogical concerns. This is not an altogether surprising result. Indeed, the Hazelwood Court itself suggested a broad conception when it included among its list of permissible restrictions those made on the basis of the "emotional maturity of the intended audience." ${ }^{, k 3}$ Following that lead, lower courts have interpreted the legitimate pedagogical concern requirement expansively. The primary source of the expansion has been an inclusion of behavioral and value-based concerns under the pedagogical umbrella. For example, the Sixth Circuit declared that "[t]he universe of pedagogical concerns is by no means confined to the academic.... [It includes] discipline, courtesy, and respect for authority." ${ }^{, 4}$

Courts have also permitted school authorities to identify the pedagogical concern being served by a particular restriction. This is consistent with a long-standing judicial practice of deference to educators. ${ }^{\mathrm{kS}}$ In its opinion recognizing the broad scope of pedagogical purposes, the Sixth Circuit observed that "[l]ocal school officials ... must obviously be accorded wide latitude in choosing which pedagogical values to emphasize, and in choosing the means through which those

82 Hazelwood's applicability increases because the set of speech that affects pedagogical concerns does not completely overlap with the set of speech that otherwise meets the requirements for school sponsorship.

83 Hazelwood, 484 US at 272.

84 Poling v Murphy, 872 F2d 757, 762 (6th Cir 1989) (holding that restrictions to encourage civility were permissible). Similarly, citing a school interest in promoting shared values, a federal district court held that a school policy requiring teachers to approve candidates for student council was reasonably related to a legitimate pedagogical concern. See Bull v Dardanelle Public School District No. 15, 745 F Supp 1455, 1460 (ED Ark 1990).

85 See, for example, Hazelwood, 484 US at 273 ("[T]he education of the Nation's youth is primarily the responsibility of parents, teachers, and state and local officials, and not of federal judges."); Epperson v Arkansas, 393 US 97, 104 (1968) ("[P]ublic education in our Nation is committed to the control of state and local authorities."). This tendency to defer is based on the view that local voters, and not the courts, are the proper body to act as a check on school board activity. Consider Board of Education v Pico, 457 US 853, 889 (1982) (Burger dissenting):

In order to fulfill its function, an elected school board must express its views on the subjects which are taught to its students. In doing so those elected officials express the views of their community; they may err, of course, and the voters may remove them. It is a startling erosion of the very idea of democratic government to have this Court arrogate to itself the power the plurality asserts today.

Consider also Tinker, 393 US at 526 (Black dissenting) (stating that the First Amendment does not compel "the teachers, parents, and elected school officials to surrender control of the American public school system"). 
values are to be promoted." ${ }^{,{ }^{* 6}}$ Taken by itself, this deference seems reasonable. But when combined with the broad judicial conception of legitimate pedagogical concerns, it places undue authority in the hands of school officials. To justify a restriction, school officials are required merely to select some pedagogical interest, and they may do so from among an extremely wide range of possibilities.

\section{The dangers of the current status of Hazelwood.}

Expansive definitions of what constitutes school-sponsored speech and legitimate pedagogical concerns, coupled with excessive deference to the judgments of school administrators, threaten students' free speech rights when viewpoints are involved. Once speech is identified as school-sponsored, courts typically defer to a school's restriction of the speech if it can make a plausible argument that any pedagogical concern is implicated. ${ }^{87}$ This problem is amplified if courts permit this argument to justify classification of the speech as schoolsponsored in the first place. This low degree of judicial oversight accorded to a viewpoint restriction may be more superficial than is necessary to account for the respective interests of the parties.

One of the primary dangers of such deferential review is that it may permit viewpoint discrimination based merely on a school's desire to avoid controversy. For example, in Fleming, the Tenth Circuit cited a string of cases holding that, "so long as the imprimatur test is satisfied, the pedagogical test is satisfied simply by the school district's desire to avoid controversy within a school environment." ${ }^{\text {,k9 }}$ While the Fleming court paid passing attention to Hazelwood's imprimatur language, it essentially abandoned it as a distinct concept when it concluded that any speech implicating a pedagogical concern is sufficient to meet the definition of school sponsorship." Under Fleming, then, a school's declared purpose of avoiding controversy appears sufficient

86 Poling, 872 F2d at 762.

87 The fact that schools have to make a link between the restriction and a pedagogical concern only after the restriction occurs contributes to the problem here. Requiring schools to precommit to a list of pedagogical concerns served by a particular activity might address this problem. But the Supreme Court has declined to place any such requirements on schools. See Hazelwood, 484 US at $273 \mathrm{n} 6$ ("We reject respondents' suggestion that school officials be permitted to exercise [ ] control ... only pursuant to specific written regulations.... We need not now decide whether such regulations are required.").

88 See note 81 and accompanying text.

89 Fleming, 298 F3d at 925-26. Cases cited by the court to support this proposition include Brody v Spang, 957 F2d 1108, 1122 (3d Cir 1992); Crosby v Holsinger, 852 F2d 801, 802 (4th Cir 1988); and Lundberg $v$ West Monona County School District, 731 F Supp 331, 338-39 (ND Iowa 1989).

90 Fleming, $298 \mathrm{~F} 3 \mathrm{~d}$ at 925 . See also note 81 and accompanying text. 
both to trigger the application of Hazelwood and to satisfy its requirements.

That viewpoint restrictions for purposes of avoiding controversy have been upheld under Hazelwood raises two larger concerns. First, it suggests the possibility that Hazelwood could be used pretextually to restrict viewpoints to which a school board objects. Because controversy may be actual or potential, present or prospective, the purpose of avoiding controversy may be quite vague and uncertain. Should apprehension of controversy be sufficient to sustain restrictions on viewpoint expression, a school board could block the expression of disagreeable points of view simply by claiming that controversy may result. This is not a new concern. In his Hazelwood dissent, Justice Brennan worried that schools might take advantage of the "vaporous" notion of topic sensitivity to "achieve ends that cannot permissibly be achieved through blatant viewpoint discrimination.", The development of Hazelwood jurisprudence, which has approved pedagogical concerns such as civility and avoidance of controversy, has substantiated Justice Brennan's unease.

An associated concern is that avoidance of controversy as a basis for viewpoint discrimination is too simplistic. It essentially abandons Tinker's requirement that judges weigh a student's expressive rights against a school's interest in restricting access to controversial topics. Tinker rejected what was essentially an effort by the school board to avoid controversy, albeit in a "pure" speech context, by denying students the right to express themselves. The Court declared that "free speech is not a right that is given only to be so circumscribed that it exists in principle but not in fact." ${ }^{, 92}$ This reflects the Court's concern that educators and administrators might overvalue classroom control at the expense of students' free speech. A rigorous consideration of interests is required to ensure that countervailing expressive rights are not so circumscribed as to be illusory. This is particularly true when dealing with student interests as important as viewpoint expression and with claims of pedagogical purpose as generic and indeterminate as avoidance of controversy.

\section{INTERMEDIATE APPROACHES TO VIEWPOINT RESTRICTIONS UNDER HAZELWOOD}

Rather than adopting a categorical approach to the question of whether viewpoint-based restrictions are permitted under Hazelwood, courts should pursue an intermediate approach. This Part discusses two possibilities. Each increases protections of viewpoint expression

91 Hazelwood, 484 US at 287 (Brennan dissenting).

92 Tinker, 393 US at 513. 
within the existing framework of the Supreme Court's student speech jurisprudence. ${ }^{93}$ The first would require closer judicial scrutiny of the speech restriction and of the pedagogical concern asserted to justify it. The second would require a more stringent definition of the imprimatur concept. Both affect the scope of the Hazelwood holding.

\section{A. Courts Should More Vigorously Analyze Restrictions When Viewpoints Are Involved}

The judicial tradition of deference to school boards is reasonable in many educational contexts. School boards are elected bodies representing the community, and democratic safeguards exist to control the school boards' choices. In most cases, operational and educational decisions should be left to these bodies, and judges should refrain from substituting their own conclusions for those of a local school board. However, courts should not always be deferential. Indeed, the history of cases involving student expression demonstrates a need for a judicial role in educational matters. ${ }^{34}$ In Epperson v Arkansas, ${ }^{\text {"s }}$ the Supreme Court clearly recognized this in declaring judicial deference unwarranted when a school board's actions "directly and sharply implicate basic constitutional values." Instead, when constitutional rights are at issue, courts must scrutinize the school's purposes and measure the school's interests against the student's rights.

Judicial scrutiny is particularly warranted in cases involving viewpoint restrictions of school-sponsored speech. Because the expression of a viewpoint is a clearly established and highly protected constitutional right," absolute deference to school board decisions when viewpoint restrictions are involved is inappropriate under Epperson. Restriction of viewpoints should be permitted only on the basis of a careful judicial analysis of the rights involved, and not on the basis of sweeping judicial deference to a school's own identification of a legitimate pedagogical interest." This analysis must take place within the

93 A different approach would be to simply conclude that Hazelwood was wrongly decided, or at least that it should not be applied to the specific case of viewpoint-based restrictions. However, those arguments are not the project of this Comment. Instead, the goal here is to develop ways to protect student expression within the existing legal framework.

94 For example, the decision to suspend students for wearing black armbands was certainly related to a school's conception of how best to operate the schools. See Tinker, 393 US 503. The same can be said of the school board's decision to require students to salute the American flag. See West Virginia State Board of Education v Barnette, 319 US 624 (1943). Yet, in neither case did the Court simply defer to the decisions made by school officials.

95393 US 97 (1968).

96 Id at 104.

97 See text accompanying note 8.

98 The dissenting opinion in Planned Parenthood of Southern Nevada, Inc v Clark County School District, 941 F2d 817 (9th Cir 1991), reflects this logic: 
framework established by Hazelwood, which permits restrictions of school-sponsored speech that are "reasonably related to legitimate pedagogical concerns." Although this is a permissive standard, at least two avenues exist for the introduction of judicial scrutiny to increase protection of student expression.

1. The legitimacy of pedagogical concerns must be evaluated in light of the restriction sought.

The range of pedagogical concerns considered "legitimate" to sustain a restriction should vary depending on the characteristics of the speech sought to be restricted. In the case of content restrictions, it may be appropriate to consider virtually any identifiable pedagogical purpose legitimate. Determining the scope of content provided to students is a recognized part of the school's function," and restrictions made in the interest of performing that function may be presumptively permissible. However, because viewpoint restrictions are more constitutionally suspect than content regulations, and because restricting expression of a disagreeable viewpoint is arguably not the function of schools, ${ }^{101}$ they are not properly justified by an association with just any pedagogical purpose. Instead, the legitimacy requirement should be read to require a more significant purpose in order to account for the heightened interest in viewpoint expression.

One manifestation of this principle is that the avoidance of controversy should not be considered a legitimate pedagogical

At bottom, then, the majority's opinion reflects a judicial mindset that, anytime a First Amendment issue can be said to arise out of the "school environment," decisions of school authorities restricting protected expression will receive minimal scrutiny. The majority is correct that we are not school board members. But we are Article III judges, entrusted with the responsibility to review official action to ensure that it does not offend constitutional norms.

Id at 844 (Norris dissenting).

99 Hazelwood, 484 US at 273.

100 See, for example, Board of Education v Pico, 457 US 853, 864-65 (1982).

101 For an excellent statement of this view, see Hedges $v$ Wauconda Community School District No. 118,9 F3d 1295, 1299 (7th Cir 1993):

School districts seeking an easy way out try to suppress private speech. Then they need not cope with the misconception that whatever speech the school permits, it espouses. Dealing with misunderstandings - here, educating the students in the meaning of the Constitution and the distinction between private speech and public endorsement - is, however, what schools are for. ... Yet Wauconda proposes to throw up its hands, declaring that because misconceptions are possible it may silence its pupils, that the best defense against misunderstanding is censorship. What a lesson Wauconda proposes to teach its students! Far better to teach them about the first amendment, about the difference between private and public action, about why we tolerate divergent views. Public belief that the government is partial does not permit the government to become partial. Students therefore may hand out literature even if the recipients would misunderstand its provenance. The school's proper response is to educate the audience rather than squelch the speaker. 
purpose when viewpoint restrictions are contemplated. Although some courts have concluded that avoidance of controversy lies within the ambit of legitimate pedagogical concerns, ${ }^{1 / 2}$ such conclusions should be limited to cases that do not involve viewpoint restrictions. This limitation guards against the possibility that students will be treated as "closed-circuit recipients of only that which the State chooses to communicate."

\section{Legitimate pedagogical concerns must not be} purely pretextual.

Courts should also undertake an analysis of the board's actions to determine whether they were in fact motivated by the pedagogical concern claimed. Shortly after Hazelwood, a California appellate court did just that. ${ }^{1.4}$ The court rejected the argument that restrictions should be permitted whenever a school can identify any pedagogical interest related to the speech," observing that to do so "would permit school officials to camouflage religious 'viewpoint discrimination' and would be tantamount to vesting an absolute discretion in the board to determine the curriculum[,] which we do not believe Hazelwood intended." Accordingly, the court concluded that "the true motives of the school board members must be examined to answer a First Amendment challenge." This decision is consistent with the Supreme Court's plurality opinion in Board of Education $v$ Pico, ${ }^{110 \times}$ which noted that "the First Amendment rights of students may be directly and sharply implicated by the removal of the books from the shelves of a school library," and which held that scrutiny of the school's intentions was warranted to examine whether the removal was based on an unconstitutional desire to restrict viewpoints to which the school board objected.'

102 See note 89 and accompanying text.

103 Tinker, 393 US at 511. In Tinker, the Supreme Court emphasized that the school chose not to reprimand all students wearing symbolic attire, but only those expressing an anti-war stance, and then concluded that "the prohibition of expression of one particular opinion, at least without evidence that it is necessary to avoid material and substantial interference with schoolwork or discipline, is not constitutionally permissible." Id.

104 See McCarthy v Fletcher, 207 Cal App 3d 130, 254 Cal Rptr 714 (1989).

105 Id at 724.

106 Id (internal citations omitted). This suggests that the discretion granted to school boards to determine the curriculum is limited to content. Extending that discretion to permit restrictions of viewpoint in the name of curricular discretion is objectionable.

107 Id.

108457 US 853 (1982).

109 Id at 866 .

110 Id at 872 ("Such discriminatory purposes stand inescapably condemned by our precedents."). 
The rationale of these decisions should apply in cases involving viewpoint restrictions. If a pedagogical concern is to be considered legitimate, and if it is to be properly assessed in the context of countervailing rights, it cannot simply be a subterfuge for some other design of the restriction involved." An examination of the motives and intent of the school board is therefore not only appropriate but necessary.

\section{The merits of closer scrutiny.}

Any suggestion that judicial scrutiny be increased in the educational context is likely to be met with criticism that the authority to operate schools properly rests with school boards and not with courts: ${ }^{113}$ Although the solution outlined here would reduce judicial deference to school authorities to some degree, it would by no means eradicate it. It has been expedient, pragmatic, and politically appropriate for courts to acknowledge and defer to the experience and expertise possessed by school authorities; there is no reason to advocate or expect a complete departure from this policy.

Deference to a school board, however, should not involve a complete abdication of judicial responsibilities. Courts should not desist from properly weighing the interests before them. Rather, courts should consider the record bearing on motives and intentions of the school authorities before according any deference to them. Moreover, courts should not defer at all to certain pedagogical concerns, such as avoidance of controversy, that are clearly not legitimate in the context of viewpoint expression. On the other hand, where an analysis of the record demonstrates the presence of a significant pedagogical concern and the absence of pretext, deference is appropriate. In these cases, deference is embedded into the standard applied, which requires only that courts inquire whether a reasonable relationship exists between the restriction and the legitimate pedagogical concern."

111 Hazelwood requires only that a restriction be reasonably related to a legitimate pedagogical concern. Consequently, it is only when the pedagogical concern identified by the school is determined to be purely pretextual that a restriction should be prohibited. In other words, a showing that the school board was motivated by its disapproval of the viewpoint in question should not be sufficient. If the restriction nevertheless is related to a pedagogical concern that is legitimate, the restriction may be sustained. Hazelwood, 484 US at 273 (forbidding restrictions "only when the decision to censor ... has no valid educational purpose") (emphasis added).

112 As a practical matter, proof of intent to restrict speech because of disapproval will often prove difficult. See Paul Brest, Palmer v. Thompson: An Approach to the Problem of Unconstitutional Legislative Motive, 1971 S Ct Rev 95; Dean Alfange, Jr., Free Speech and Symbolic Conduct: The Draft-Card Burning Case, 1968 S Ct Rev 1, 15-16. Nevertheless, when such an intent can be demonstrated, it should be considered.

113 See note 85.

114 In its strongest statement of its holding, the Hazelwood Court declared that "[i]t is only when the decision to censor a school-sponsored publication, theatrical production, or other vehi- 
The primary advantage of the approach described is that it recognizes the existence of legitimate but competing interests. In effect, it asks courts to do what they already do in many other contexts - to balance an expressive right against a state interest. ${ }^{115}$ Of course, it can be argued that Hazelwood itself established such a balance, and that it did so in a categorical fashion. But such a reading of Hazelwoodpermitting any restriction on the basis of a relationship to any pedagogical concern -is problematic because it fails to acknowledge that the interests involved are variable, depending on both the restriction and the nature of the pedagogical concern asserted to justify it.

\section{B. Courts Should Adopt a More Stringent Application of the Imprimatur Concept}

A different way to ensure that student viewpoints are not unduly suppressed is to narrow the scope of the school-sponsored category. Instead of applying the Hazelwood standard whenever speech implicates a pedagogical concern, courts should strictly interpret the imprimatur requirement and apply the Hazelwood standard only if the expression involved is tantamount to expression by the school itself. ${ }^{110}$ If the school is perceived to be the speaker, then its interest is so heightened that it outweighs a student's interest in viewpoint expression. In that case, restrictions in accordance with any legitimate pedagogical concern would be appropriate." On the other hand, if the student speaks on his own behalf, the school's interest is similar to cases involving pure student speech-even if the school is otherwise involved with the speech-and in that case, viewpoint restrictions should be permitted only if the standards of either Tinker or Fraser are satisfied.

Recent cases suggest the potential for a strengthened imprimatur requirement. In Rosenberger $v$ Rector and Visitors of University of Vir-

cle of student expression has no valid educational purpose that the First Amendment is so 'directly and sharply implicate[d]' as to require judicial intervention to protect students' constitutional rights." Hazelwood, 484 US at 273, quoting Epperson, 393 US at 104. But even this formulation does not preclude judicial scrutiny. First, intervention is not equivalent to analysis: Judicial analysis is appropriate in cases involving school-sponsored speech, but intervention to overturn a school's action is necessary only when there is no valid educational purpose. Furthermore, the determination of what constitutes a valid educational purpose-given the context of the restriction and the strength of the countervailing interest - is within the domain of the court.

115 Almost all cases involving speech restrictions involve a balance between state interests and expressive rights. See, for example, Rankin v McPherson, 483 US 378, 384 (1987); Board of Airport Commissioners of City of Los Angeles v Jews for Jesus, Inc, 482 US 569, 572-73 (1987); Pickering v Board of Education of Township High School District 205, 391 US 563, 568 (1968).

116 In effect, this suggestion would alter the allocation of cases between Tinker and Hazelwood. See text accompanying note 128 .

117 In the context of this application of Hazelwood, legitimate pedagogical concerns could be interpreted to include any pedagogical concern. See text accompanying note 129. 
ginia, ${ }^{118}$ the Supreme Court concluded that a university could make viewpoint-based restrictions when it speaks or "enlists private entities to convey its own message," appropriate when the university is not the effective speaker. ${ }^{121}$ Rosenberger has since been read to imply a limitation on the applicability of Hazelwood. In Saxe $v$ State College Area School District, ${ }^{121}$ the Third Circuit concluded that Rosenberger "made clear that Hazelwood's permissive 'legitimate pedagogical concern' test governs only when a student's school-sponsored speech could reasonably be viewed as speech of the school itself." ${ }^{122}$ This conclusion narrows the scope of school-sponsored speech to include only that speech which could be perceived as bearing the school's imprimatur."

Two lower court opinions further clarify the potential effects of a stricter reading of the imprimatur concept. Shortly after Hazelwood, a district court declined to expand the scope of the opinion to govern speech contained in an extracurricular high school newspaper. ${ }^{124} \mathrm{Al}-$ though supervised by faculty and funded by the school, the court refused to characterize the newspaper as "school-sponsored" because it was not a formal part of the curriculum. Student speech taking place within an educational context - and with involvement by educational officials-was not considered sufficient to trigger application of Hazelwood. ${ }^{125}$ Similarly, four years later, the Seventh Circuit refused to

118515 US 819 (1995).

119 Id at 833.

120 See id at 834 ("A holding that the University may not discriminate based on the viewpoint of private persons whose speech it facilitates does not restrict the University's own speech, which is controlled by different principles."), citing Hazelwood, 484 US at 270-72. Although the case itself concerns the university environment, the conclusions of Rosenberger are not limited to that environment. The Court did not treat the university as distinctive, and cited frequently to precedents such as Hazelwood that arose from non-university contexts.

121240 F3d 200 (3d Cir 2001).

122 Id at 213-14. At the time of Saxe, the Third Circuit had already decided Oliva, 195 F3d at 171-73, which found that viewpoint neutrality was not required by Hazelwood. See notes $62-65$ and accompanying text. The combined effect of the rulings is that viewpoint-based restrictions are allowed, but only when the speech involved is tantamount to school speech.

123 See also Downs v Los Angeles Unified School District, 228 F3d 1003, 1009 (9th Cir 2000) (citing Hazelwood for the proposition that "where [student] speech or expression begins to implicate the school as speaker, First Amendment rights have been limited"). Although decided prior to Hazelwood, Pico is also relevant here. In Pico, a fractured Supreme Court rejected the removal of books from a school library based on the possibility that the removal was based simply on the school board's disapproval of their content. 457 US at 871-72. In doing so, Justice Brennan's plurality opinion drew a distinction between the right to remove books from the school curriculum and the right to remove books from the school library. Id at 868-69. Although both actions take place within the educational context, broadly defined, only curricular books would be reasonably perceived as official school speech because student use of the library is voluntary. Id at 869 . One interpretation of this distinction is that books that are simply available in the library are within the educational context but lack the imprimatur of the school.

124 See Romano v Harrington, 725 F Supp 687 (ED NY 1989).

125 The Romano court recognized the dangers inherent in an expansive conception of 
apply Hazelwood in a case involving distribution of religious pamphlets by a middle school student. ${ }^{126}$ Despite the school's attempt to characterize the speech as school-sponsored, Judge Easterbrook rejected the notion that "whatever speech the school permits, it espouses." ${ }^{127}$ The standards applicable to school-sponsored speech are appropriate only when speech by a student may be interpreted by others as speech that the school espouses rather than permits.

Strict interpretation of the imprimatur concept would have the practical effect of redistributing cases between Hazelwood and Tinker. The allocation contemplated is as follows: When speech is merely permitted or tolerated, no risk of imprimatur exists, and Tinker would apply; when a school affirmatively promotes or espouses speech, an imprimatur exists, and Hazelwood would apply. Some cases that previously would be decided according to the standards of Hazelwood would be decided according to those of Tinker instead. ${ }^{123}$ When the speech in question is tantamount to speech by the school itself, the application of Hazelwood will necessarily result in a finding that the school's interest predominates. Particular viewpoints may be restricted in those instances because the school has a right to control its own expression. ${ }^{124}$ However, in cases where Hazelwood is not applied, restrictions would be permitted only if the speech involved were materially disruptive, ${ }^{1,30}$ offensive, or lewd in nature.

Although this approach improves protections for viewpoint expression, it does present some difficulties. First, it is overinclusive since a narrowed scope of school-sponsored speech affects cases where no viewpoint restriction exists. ${ }^{132}$ Because it lacks the flexibility to account for variations relating to the expression and the restriction, it fails to escape the weaknesses of a categorical approach.

school sponsorship: "Because educators may limit student expression in the name of pedagogy, courts must avoid enlarging the venues within which that rationale may legitimately obtain without a clear and precise directive." Id at 689.

126 See Hedges, 9 F3d at 1295, 1300-02.

127 Id at 1299. This language is evocative of the distinction drawn in Hazelwood between toleration and promotion of speech. Hazelwood, 484 US at 270-71.

128 Specifically, cases in which speech occurs within the educational context but without risk of imprimatur would be "shifted" to Tinker. Cases could also be shifted toward the framework of Fraser, but this is not very likely. If a school's restriction could be justified based on the requirements of Fraser, then the case would likely be decided on that basis. The potential for problematic applications of Hazelwood is introduced in situations where a restriction could not be sustained under either Fraser or Tinker-it is in those cases that schools have an incentive to urge an expansive application of Hazelwood.

129 Schools are granted wide authority to regulate official speech. See note 12.

130 See Tinker, 393 US at 513.

131 See Fraser, 478 US at 685-86.

132 This is not necessarily a fatal criticism. After all, the Third Circuit's conclusions in Saxe were not limited to cases involving viewpoint restrictions, but were applicable to all restrictions of student speech. See Saxe, 240 F3d at 213-14. 
More importantly, this approach is difficult to square with Hazelwood itself. Although Hazelwood emphasized the importance of the school's imprimatur to substantiate a heightened regulatory interest, the imprimatur was only one of several factors that figured into the analysis. ${ }^{133}$ To adopt an approach that is effectively determined by the imprimatur inquiry is to undermine the importance of those other factors. Thus, while this approach would have the welcome effect of improving protections for the expression of student viewpoints, it has other incidental effects that limit its appeal.

\section{CONCLUSION}

When speech is affirmatively promoted by a school, educational authorities are rightfully granted considerable authority to make restrictions in accordance with legitimate pedagogical concerns. But the right to viewpoint expression is important enough that care must be taken to ensure that the school's authority is not used simply to restrict viewpoints on the basis of disapproval or a desire to avoid controversy. Instead, courts should pursue an analytical approach that enables careful consideration of the relative interests involved.

Both of the general proposals suggested in this Comment provide greater protection for viewpoint expression within the established framework of Hazelwood analysis. The first approach does so by increasing the level of judicial scrutiny applied to a school's restriction of viewpoint expression. This increased scrutiny would consider a school's pedagogical purpose to be legitimate only when it is not purely pretextual and is sufficient to outweigh a student's interest in viewpoint expression. The second approach provides increased viewpoint protection by decreasing the scope of Hazelwood to include only cases where student speech might reasonably be confused with official speech. This would effectively shift some cases away from the Hazelwood framework and toward the more protective Tinker framework. ${ }^{1.4}$ However, this latter approach would reintroduce an undesirable degree of rigidity of analysis. As a result, the first proposal's focus on legitimacy is superior, and should be pursued by courts faced with viewpoint restrictions of student school-sponsored speech.

133 See Hazelwood, 484 US at 270-73 (discussing other factors involved in determining permissibility of restrictions).

134 It is not necessary to apply both proposals to achieve the desired result. If judicial scrutiny is introduced to weigh a pedagogical interest against an expressive interest, then viewpoint restrictions will be permitted only when the pedagogical interest predominates, regardless of whether the speech involved bears the school's imprimatur. On the other hand, if the scope of school-sponsored speech is narrowed, then increased scrutiny need not be pursued. Instead. courts could continue to defer to school board officials and apply an expansive conception of legitimate pedagogical concerns. A court's evaluation of whether an imprimatur existed would be sufficient to safeguard the student's interest in viewpoint expression. 


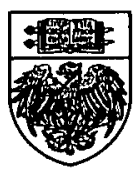

